\title{
SARS-CoV-2 RNA stability in saliva and dry swabs for storage and transport at ambient temperature for at least 9 days: A cost efficient and practical alternative
}

\author{
Alonzo Alfaro-Núñez ${ }^{1}$, Stephanie Crone ${ }^{2}$, Shila Mortensen ${ }^{1}$, Maiken Worsøe Rosenstierne ${ }^{1}$, \\ Anders Fomsgaard ${ }^{1}$, Ellinor Marving ${ }^{1}$, Sofie Holdflod Nielsen ${ }^{2}$, Michelle Grace Pinto \\ Jørgensen $^{2}$, Arieh S. Cohen ${ }^{2}$, and Claus Nielsen ${ }^{1}$ \\ ${ }^{1}$ Statens Serum Institut Virus og Mikrobiologisk Specialdiagnostik \\ ${ }^{2}$ Statens Serum Institut
}

May 13, 2021

\begin{abstract}
During the current COVID-19 pandemic, different methods have been used to evaluate patients suspected with infection of SARS-CoV-2. In this study, we evaluate the longevity of saliva and dry swab samples to retain SARS-CoV-2 for storage and transport at different environmental settings. Our results show that at ambient temperature of $20^{\circ} \mathrm{C}, \mathrm{SARS}-\mathrm{CoV}-2 \mathrm{RNA}$ remains stable for up to 9 days giving a long span of time for transport and storage without compromising clinical results. Additionally, this study demonstrates that saliva and dry swabs specimens can also be stored at $-20^{\circ} \mathrm{C}$ and $+4^{\circ} \mathrm{C}$ for up to 26 days without affecting RT-qPCR results. Our data is relevant for low-and middle-income countries, which have limited access to rapid refrigerated transport and storage of samples representing an economical alternative. Finally, our study demonstrates that dry swabs provide clear advantages over using transport medium.
\end{abstract}

\section{Hosted file}

SARS-CoV-2 RNA stability in saliva and dry swabs_05May21_v1.pdf available at https: //authorea.com/users/413685/articles/521929-sars-cov-2-rna-stability-in-saliva-anddry-swabs-for-storage-and-transport-at-ambient-temperature-for-at-least-9-days-a-costefficient-and-practical-alternative 
Viral copies/ $\mu \mathrm{l}$
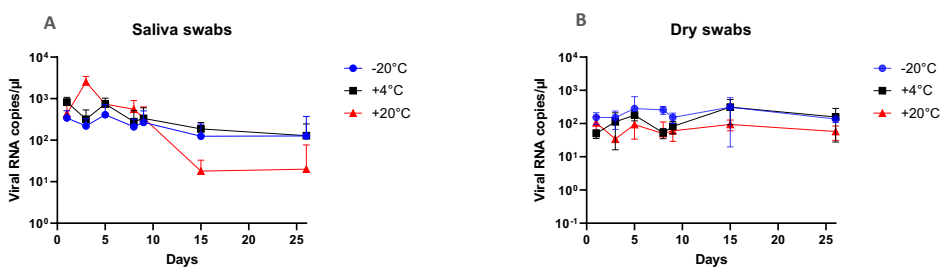

Ct values
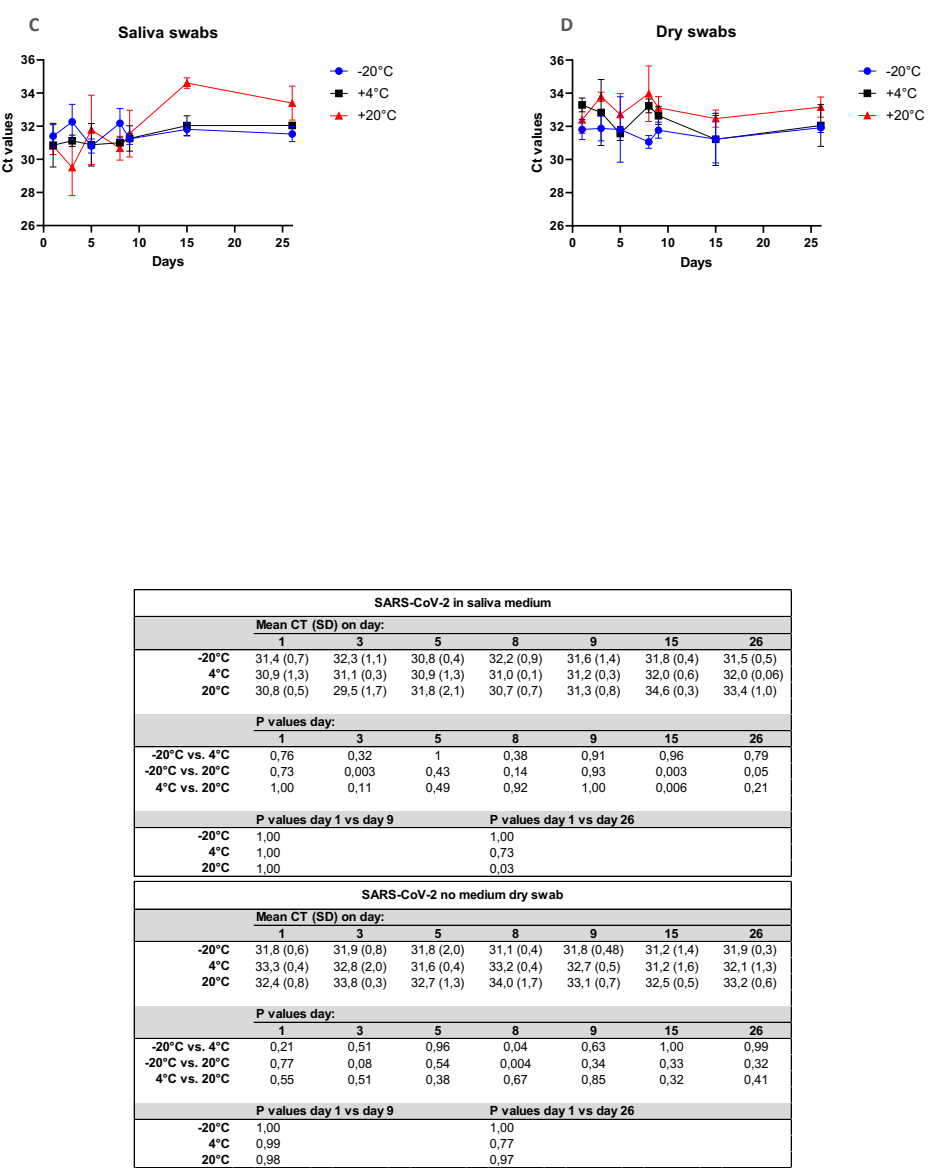

\section{Hosted file}

Table_1.pdf available at https://authorea.com/users/413685/articles/521929-sars-cov-2-rnastability-in-saliva-and-dry-swabs-for-storage-and-transport-at-ambient-temperature-forat-least-9-days-a-cost-efficient-and-practical-alternative 